\title{
Effects of Liraglutide Combined with Insulin on Oxidative Stress and Serum MCP-1 and NF-kB Levels in Type 2 Diabetes
}

\author{
Xia Liu1, Jinwen Huang2, Jiawei Li33, Qinghua Mao4 and Jirui $\mathrm{He}^{1}$
}

\begin{abstract}
Objective: To investigate the effects of liraglutide combined with insulin on oxidative stress and expression levels of serum monocyte chemoattractant protein-1 (MCP-1) and nuclear factor- $\mathrm{kB}(\mathrm{NF}-\mathrm{kB})$ in patients with type 2 diabetes.

Study Design: An experimental study.

Place and Duration of Study: Department of Endocrinology, the Second Hospital Affiliated to Lanzhou University, China, from September 2016 to January 2018.

Methodology: Ninety-two patients with type 2 diabetes were selected as objects of study. They were randomly divided into observation group and control group, with 46 cases in each group. The control group was treated with insulin alone, and the observation group was treated with liraglutide in combination with insulin. The changes of levels of blood glucose, serum MDA, SOD, MCP-1 and NF-kB were compared between the two groups before and after treatment, and the blood glucose target rate after treatment was compared between the two groups.

Results: Before treatment, there were no significant differences in fasting blood glucose, $2 \mathrm{~h}$ postprandial blood glucose, serum MDA, serum SOD, serum MCP-1 and serum NF-kB between the two groups $(p=0.885,0.961,0.919,0.990,0.954$ and 0.837 , respectively). After treatment, levels of the fasting blood glucose, $2 \mathrm{~h}$ postprandial blood glucose, serum MDA, serum MCP-1, and serum NF-kB in the observation group were lower than those in the control group (all $p<0.001)$. The serum SOD level and blood glucose target rate were higher in the observation group than those in the control group $(p<0.001$ and $p=0.010$, respectively).

Conclusion: Liraglutide combined with insulin therapy can effectively improve blood glucose levels in type 2 diabetic, reduce oxidative stress status, decrease the expression of serum MCP-1 and NF- $\mathrm{kB}$, and inhibit the internal inflammatory response.
\end{abstract}

Key Words: Liraglutide, Insulin, Type 2 diabetes, Blood glucose, MCP-1, NF-кB.

\section{INTRODUCTION}

Type 2 diabetes is a chronic disease with abnormal blood glucose levels caused by insulin resistance and insufficient insulin secretion. ${ }^{1}$ Insufficient insulin secretion is associated with defects in $\beta$ cell function. The mechanism that triggers the defect of pancreatic $\beta$ cell function is complicated. It is currently believed that the level of oxidative stress in the body is closely related to the function of pancreatic $\beta$ cells. ${ }^{2}$ Studies have shown that monocyte chemoattractant protein-1 (MCP-1) and nuclear factor- $\kappa \mathrm{B}(\mathrm{NF}-\kappa \mathrm{B})$ play an important role in courses of chronic diseases such as type 2 diabetes. ${ }^{3}$ Glucagon-like peptide-1 (GLP-1) is an important incretin, which is secreted by the distal small intestine L-cell after

1 Department of Endocrinology, The Second Hospital Affiliated to Lanzhou University, 730030, China

2 Department of Anesthesiology, Gansu People's Hospital, 730000, China

3 College of Basic Medicine, Gansu University of Traditional Chinese Medicine, 730000, China

4 Clinical Laboratory, The First People's Hospital of Jining, 272002, China

Correspondence: Jirui He, Department of Endocrinology, The Second Hospital Affiliated to Lanzhou University, 730030, China

E-mail:ncera1@163.com

Received: July 09, 2018; Accepted: October 10, 2018 ingestion of food by the human body. ${ }^{4}$ GLP-1 promotes insulin secretion when glucose concentration is elevated, and inhibits the action of insulin to antagonize glucagon secretion. For this reason, GLP-1 becomes a glucose-dependent hypoglycemic factor in the incretin family, and its therapeutic effect on type 2 diabetes is worthy of attention. 5 Liraglutide is a glucagon-like peptide-1 (GLP-1) analogue synthesized by genetic recombination technology that retains the efficacy of native GLP-1.6 In in vitro studies, it has been demonstrated that liraglutide can inhibit interleukin-1 $\beta$-induced $\beta$ cell apoptosis and induce proliferation of human islet cells. ${ }^{7}$ In animal studies, it has found that liraglutide can promote pancreatic $\beta$ cell proliferation in diabetic mice. ${ }^{8}$ Liraglutide can improve the implantation and function of marginal islet cells in transplants and transplanted mice, in order to reduce the apoptosis of $\beta$ cells after 48 hours of transplantation. ${ }^{9}$

The purpose of this study was to investigate the effects of liraglutide combined with insulin on oxidative stress and serum MCP-1 and NF-kB in patients with type 2 diabetes, hoping to provide reference for clinical treatment of type 2 diabetes.

\section{METHODOLOGY}

This study was conducted at Department of Endocrinology, the Second Hospital Affiliated to Lanzhou University, 
China, from September 2016 to January 2018. It was conducted after approval from the Hospital Ethical and Research Committee. A total of 92 patients with type 2 diabetes were selected as study objects. Exclusion criteria were patients with diabetic ketoacidosis, hyperosmolar syndrome, history of acute or chronic pancreatitis, gestation and lactation period, patients with heart, kidney, liver and other organ damage, and those on oral hypoglycemic agents or insulin. Consent was obtained from patients and their families.

Ninety-two patients were randomly divided into observation group and control group with 46 cases in each group. All patients were given diet control and exercise intervention. The control group was given insulin aspart 30 injection (NovoRapid 30) 0.3-0.5 U/(kg/d), administered 15 minutes before breakfast and dinner. The observation group was additionally given liraglutide $0.6 \mathrm{mg} /$ time, four times a day. Both groups of patients took 12 weeks as the course of treatment.

The blood glucose indices (fasting blood glucose, and $2 \mathrm{~h}$ postprandial blood glucose), serum oxidative stress related indicators (MDA, SOD), serum MCP-1 and NF-kB were compared between the two groups before and after treatment. Fasting blood glucose and $2 \mathrm{~h}$ postprandial blood glucose were measured by glucose oxidase method. Malondialdehyde (MDA) was detected by thiobarbituric acid colorimetric method, and superoxide dismutase (SOD) was detected by hydroxylamine method. MCP-1 and NF-kB were detected by enzymelinked immunosorbent assay (ELISA). After treatment, the blood glucose target rate of the two groups was judged by fasting blood glucose $<7 \mathrm{mmol} / \mathrm{L}$ and $2 \mathrm{~h}$ postprandial blood glucose $<9 \mathrm{mmol} / \mathrm{L}$. Blood glucose target rate $(\%)=$ number of patients reached blood glucose target / number of patients $\times 100 \%$.

SPSS 23.0 software was adopted for data statistical analysis. Enumeration data showed in $\mathrm{n}(\%)$, examined by $\mathrm{X}^{2}$ test. Measurement data showed in Mean $\pm S D$, examined by independent sample t-test. $\mathrm{P}<0.05$ means that there was statistical significance in the difference.

\section{RESULTS}

Among 92 patients, 50 males (54.35\%) and 42 females (45.65\%); aged $30-65$ years, with mean age $56.37 \pm 4.15$ years; duration of disease 1-16 years, mean disease duration $9.85 \pm 1.34$ years; 16 cases (17.39\%) accompanied with hypertension history and 14 cases $(15.22 \%)$ with hyperlipidemia.

There was no significant difference in fasting blood glucose and $2 \mathrm{~h}$ postprandial blood glucose between the two groups before treatment $(p=0.885$ and 0.961 , respectively). After treatment, the fasting blood glucose and $2 \mathrm{~h}$ postprandial blood glucose were lower in the observation group than in the control group (both
Table I: Comparison of blood glucose between the two groups.

\begin{tabular}{l|l|c|c|c}
\hline Index & Time & $\begin{array}{c}\text { Control } \\
\text { group } \\
(\mathrm{n}=46)\end{array}$ & $\begin{array}{c}\text { Observation } \\
\text { group } \\
(\mathrm{n}=46)\end{array}$ & p-value \\
\hline Fasting blood glucose & Before treatment & $9.58 \pm 1.20$ & $9.53 \pm 2.01$ & 0.885 \\
(mmol/L) & After treatment & $7.37 \pm 0.69$ & $6.25 \pm 1.20$ & $<0.001$ \\
\hline 2h postprandial blood & Before treatment & $11.34 \pm 3.33$ & $11.31 \pm 2.39$ & 0.961 \\
glucose (mmol/L) & After treatment & $9.56 \pm 1.14$ & $7.04 \pm 1.33$ & $<0.001$ \\
\hline
\end{tabular}

Table II: Comparison of serum oxidative stress indexes between the two groups.

\begin{tabular}{l|l|c|c|c}
\hline Index & Time & $\begin{array}{c}\text { Control } \\
\text { group } \\
(\mathrm{n}=46)\end{array}$ & $\begin{array}{c}\text { Observation } \\
\text { group } \\
(\mathrm{n}=46)\end{array}$ & p-value \\
\hline MDA (mmol/L) & Before treatment & $4.85 \pm 0.65$ & $4.83 \pm 1.16$ & 0.919 \\
& After treatment & $3.86 \pm 1.27$ & $3.02 \pm 0.32$ & $<0.001$ \\
\hline SOD(U/L) & Before treatment & $79.91 \pm 5.96$ & $79.93 \pm 8.68$ & 0.990 \\
& After treatment & $85.24 \pm 8.94$ & $94.15 \pm 13.37$ & $<0.001$ \\
\hline
\end{tabular}

Table III: Comparison of serum MCP-1 and NF- $\mathrm{kB}$ levels between the two groups.

\begin{tabular}{l|l|c|c|c}
\hline Index & Time & $\begin{array}{c}\text { Control } \\
\text { group } \\
(\mathrm{n}=46)\end{array}$ & $\begin{array}{c}\text { Observation } \\
\text { group } \\
(\mathrm{n}=46)\end{array}$ & p-value \\
\hline $\mathrm{MCP}-1(\mathrm{pg} / \mathrm{mL})$ & Before treatment & $324.51 \pm 53.33$ & $323.86 \pm 55.22$ & 0.954 \\
& After treatment & $259.50 \pm 53.70$ & $215.39 \pm 57.08$ & $<0.001$ \\
\hline NF-кB $(\mathrm{pg} / \mathrm{mL})$ & Before treatment & $366.58 \pm 46.15$ & $364.63 \pm 44.30$ & 0.837 \\
& After treatment & $281.17 \pm 53.46$ & $235.06 \pm 43.20$ & $<0.001$ \\
\hline
\end{tabular}

$p<0.001$, Table I). After treatment, the blood glucose target rate of the observation group was $84.78 \%$ (39 cases), which was higher than that of the control group $(60.87 \%, 28$ cases). The difference was statistically significant $(p=0.010)$.

Before treatment, there was no significant difference in serum MDA and SOD levels between the two groups $(p=0.919$ and 0.990 , respectively). After treatment, the serum MDA level of the observation group was lower than that of the control group $(p<0.001)$, and the SOD level was higher than the control group $(p<0.001$, Table II).

There was no significant difference in serum MCP-1 and $\mathrm{NF}-\kappa \mathrm{B}$ levels between the two groups before treatment $(p=0.954$ and 0.837 , respectively). After treatment, the serum levels of MCP-1 and NF- $\mathrm{KB}$ in the observation group were lower than those in the control group (both $\mathrm{p}<0.001$, Table III).

\section{DISCUSSION}

In patients with type 2 diabetes, the physiological performance of insulin is reduced, which causes an increase in blood glucose, and an irreversible exhaustion of the pancreatic $\beta$ cells. Effective control of blood glucose not only prevents and delays diabetic retinopathy, but also reduces the incidence of neuropathy. 10 Liraglutide is a novel hypoglycemic agent that is a receptor agonist of human glucagon-like peptide-1 (GLP-1), which is a polypeptide consisting of 39 amino acids with one amino acid substitution 
(Arg34Lys) and $1 \mathrm{C}-16$ palmitic acid side chain linked by a glutamyl spacer region. ${ }^{11}$ Liraglutide has the effects of inhibiting glucagon secretion, promoting pancreatic $\beta$ cell proliferation, inhibiting apoptosis, improving pancreas islet function, suppressing appetite, reducing body mass, etc. 12 The results of this study showed that the blood glucose level of the observation group was more controlled than that of the control group after treatment, and the blood glucose target rate was higher, which was consistent with other studies. 13

Oxidative stress response is an important change in the body under high glucose conditions, and is also an important pathological link that mediates diabetic microvascular complications. ${ }^{14}$ Activation of oxidative stress causes a large number of oxygen-free radicals to form, which oxidizes with microvascular endothelial cells and glomerular basement membrane cells and causes cell damage, which will further cause proteins to leak through the glomerulus and enter the urine, causing proteinuria. 15,16 MDA is a lipid peroxide degradation product that reflects the degree of damage of oxygenfree radicals to cells. ${ }^{17}$ SOD is a scavenger that eliminates harmful substances produced by organisms during metabolism. It can specifically scavenge oxygenfree radicals and restore cell function. ${ }^{18}$ In this study, it is found that after treatment, the serum SOD expression of the observation group was higher than that of the control group, and the MDA expression was lower than that of the control group. It indicates that the addition of liraglutide in the observation group can reduce the oxidative stress in the body.

MCP-1 is a cellular chemotactic factor, an inflammatory cytokine that is specific for monocyte chemotactic proteins and can bind to NF- $\mathrm{KB}$ nuclear factor DNA to activate the gene transcription system. ${ }^{19} \mathrm{NF}-\kappa \mathrm{B}$ has the function of regulating inflammatory transcription factors. Under normal conditions, binding to NF-KB inhibitory protein in cytoplasm is non-activated. Once activated, it can induce TNF- $\alpha$, IL-6, cell adhesion molecules, etc., regulate the expression of genes and participate in the occurrence and development of diabetes. 20

In this study, it was found that after treatment, the levels of MCP-1 and NF-KB in the observation group were significantly lower than those in the control group. This indicates that liraglutide combined with insulin therapy can reduce the inflammatory response in patients with type 2 diabetes. The mechanism may be a synergistic effect, and a joint inhibition of the production and release of inflammatory factors in those patients with type 2 diabetes.

\section{CONCLUSION}

Liraglutide combined with insulin therapy can effectively improve blood glucose levels in type 2 diabetics, reduce oxidative stress status, decrease the expression of serum MCP-1 and NF-kB, and inhibit the internal inflammatory response.

\section{REFERENCES}

1. Bellamy L, Casas JP, Hingorani AD, Williams D. Type 2 diabetes mellitus after gestational diabetes: a systematic review and meta-analysis. Lancet 2009; 373:1773-9.

2. Robertson RP, Harmon JS. Pancreatic islet beta-cell and oxidative stress: the importance of glutathione peroxidase. Febs Lett 2007; 581:3743-8.

3. Aljada A, Ghanim H, Saadeh R, Dandona P. Insulin inhibits NFkappaB and MCP-1 expression in human aortic endothelial cells. J Clin Endocrinol Metab 2001; 86:450-3.

4. Parkes DG, Mace KF, Trautmann ME. Discovery and development of exenatide: the first antidiabetic agent to leverage the multiple benefits of the incretin hormone, GLP-1. Expert Opin Drug Discov 2013; 8:219-44.

5. Ahrén B. GLP-1 for type 2 diabetes. Exp Cell Res 2011; 317: 1239-45.

6. Dharmalingam M, Sriram U, Baruah MP. Liraglutide: A review of its therapeutic use as a once daily GLP-1 analog for the management of type 2 diabetes mellitus. Indian $\mathrm{J}$ Endocrinol Metab 2011; 15:9-17.

7. Bregenholt S, Møldrup A, Blume N, Karlsen AE, Nissen Friedrichsen $\mathrm{B}$, Tornhave $\mathrm{D}$, et al. The long-acting glucagonlike peptide-1 analogue, liraglutide, inhibits beta-cell apoptosis in vitro. Biochem Biophys Res Commun 2005; 330:577-84.

8. Rolin B, Larsen MO, Gotfredsen CF, Deacon CF, Carr RD, Wilken $\mathrm{M}$, et al. The long-acting GLP-1 derivative NN2211 ameliorates glycemia and increases beta-cell mass in diabetic mice. Am J Physiol Endocrinol Metab 2002; 283:E745-52.

9. Merani S, Truong W, Emamaullee JA, Toso C, Knudsen LB, Shapiro AM. Liraglutide, a long-acting human glucagon-like peptide 1 analog, improves glucose homeostasis in marginal mass islet transplantation in mice. Endocrinology 2008; 149: 4322-8.

10. Kroc Collaborative Study Group. Blood glucose control and the evolution of diabetic retinopathy and albuminuria: a preliminary multicenter trial. N Engl J Med 1984; 311:365-72.

11. Croom KF, Mccormack PL. Liraglutide: a review of its use in type 2 diabetes mellitus. Drugs 2009; 69:1985-2004.

12. Shimoda M, Kanda $Y$, Hamamoto $S$, Tawaramoto $K$, Hashiramoto $\mathrm{M}$, Matsuki $\mathrm{M}$, et al. The human glucagon-like peptide-1 analogue liraglutide preserves pancreatic beta cells via regulation of cell kinetics and suppression of oxidative and endoplasmic reticulum stress in a mouse model of diabetes. Diabetologia 2011; 54:1098-108.

13. Appel LJ, Sacks FM, Carey VJ, Obarzanek E, Swain JF, Miller ER, et al. Effects of protein, monounsaturated fat, and carbohydrate intake on blood pressure and serum lipids: results of the OmniHeart randomized trial. JAMA 2005; 294: 2455-64.

14. Hanefeld M, Appelt D, Engelmann K, Sandner D, Bornstein SR, Ganz X, et al. Serum and plasma levels of vascular endothelial growth factors in relation to quality of glucose control, biomarkers of inflammation, and diabetic nephropathy. Horm Metab Res 2016; 48:529-34. 
15. Tykhomyrov AA, Shram SI, Grinenko TV. Role of angiostatins in diabetic complications. Biomed Khim 2015; 61:41-56.

16. Lindblom R, Higgins G, Coughlan M, de Haan JB. Targeting mitochondria and reactive oxygen species-driven pathogenesis in diabetic nephropathy. Rev Diabet Stud 2015; 12: 134-56.

17. Cao HX, He LQ, Shen YJ. Changes of SOD, GSH and MDA in renal tissues of diabetic hyperlipidemia rats. Zhong Xi Yi Jie He Xue Bao 2004; 2:36-8.

18. Padalkar RK, Shinde AV, Patil SM. Lipid profile, serum malondialdehyde, superoxide dismutase in chronic kidney diseases and type 2 diabetes mellitus. Biomed Res 2012; 23: 207-10.

19. Harada C, Okumura A, Namekata K, Nakamura K, Mitamura Y, Ohguro $\mathrm{H}$, et al. Role of monocyte chemotactic protein-1 and nuclear factor kappa $B$ in the pathogenesis of proliferative diabetic retinopathy. Diabetes Res Clin Pract 2006; 74:249-56.

20. Sun X, Han F, Yi J, Han L, Wang B. Effect of aspirin on the expression of hepatocyte NF-KB and serum TNF- $\alpha$ in streptozotocin-induced type 2 diabetic rats. J Korean Med Sci 2011; 26:765-70.

.......... 